\begin{abstract}
Vegard Bruun Wyller (f. 1972) er medisinsk redaktør i Tidsskriftet. Han er overlege ved Barne- og ungdomsklinikken, Akershus universitetssykehus, og professor ved Institutt for klinisk medisin, Universitetet i Oslo.
\end{abstract}

\title{
Helsepolitikk - mer ideologi enn fornuft?
}

Legeyrket forutsetter fornuft. Vi kan være uenige om $h v a$ som er fornuftig i en gitt situasjon, og vi kan også diskutere ulike typer av fornuft. Men ingen betviler nødvendigheten av fornuft i seg selv, herunder at medisinsk praksis må korrigeres av erfaringer.

Dette er et adelsmerke, men kan samtidig hemme oss i forståelsen av helsepolitikk. Vår vektlegging av rasjonalitet kan gjøre oss blinde for at politiske prosesser ikke trenger å ha noen rasjonell begrunnelse i det hele tatt. For eksempel vil mange automatisk anta at reformer i helsevesenet tross alt er basert på fornuftige overveielser, som kostnad-nytte-vurderinger. Selv om pasientbehandlingen skulle bli dårligere, tror vi at reformene er økonomisk hensiktsmessige og at samfunnet sparer penger. Ut fra en slik forståelse kan reformene oppfattes som umoralske, men ikke ufornuftige.

Men kanskje samfunnet $i k k e$ sparer penger. Kanskje reformene ikke er basert på fornuftsvurderinger, men på ideologi. I samfunnsforskningen betyr ideologi sosialt bestemte virkelighetsoppfatninger om politikk og samfunn og har ifølge noen fagtradisjoner fem kjennetegn (1): realitetsfordreining, som innebærer at erfaringer ikke virker korrigerende, selvimmunisering, det vil si iboende forsvarsmekanismer mot truende kritikk, interesseavhengighet, det vil si at ideologien fremmer bestemte særinteresser (ofte forkledt som allmenninteresser), en skadelidende part, altså at noen taper på ideologiens tilstedeværelse, systemsammenheng, det vil si et sammenhengende tankesett der enkeltoppfatninger begrunner hverandre.

Ledende samfunnsforskere har argumentert for at norsk politikk er mer ideologisk begrunnet enn mange antar $(1,2)$. Innenfor helsefeltet er danningen av Oslo universitetssykehus (OUS) et interessant studieobjekt. Kan man her gjenfinne de fem kjennetegnene på en ideologisk drevet prosess? Realitetsfordreining synes å ha vært til stede: Oslo universitetssykehus ble formelt etablert i 2009, men allerede i 2002 forelå det en omfattende oversiktsartikkel fra Storbritannia der det ble dokumentert at sykehusfusjoner ikke ga effektiviseringsgevinster eller økonomisk innsparing (3). Tilsvarende funn var gjort $i$ andre land (4), samtidig som økonomer med et mer teoretisk utgangspunkt advarte mot svekket effektivitet (5). Likevel ble det hevdet at prosessen raskt ville gi en inntjening på 900 millioner kroner per år (6), mens fasiten ble et betydelig økonomisk tap de første driftsårene. Hva med selvimmunisering? Kravet om lojalitet til fusjonsprosessen (7) og de kraftige sanksjonene mot dem som brøt med dette (8) kan fortolkes som uttrykk for et slikt fenomen. Forelå det en interesseavhengighet? I alle fall økonomisk: Regningen fra ulike konsulentselskaper var samlet på ca. 3 milliarder kroner (2). I tillegg innebar prosessen en maktforskyvning fra faglig og politisk nivå til forvaltningsnivå (2). Finnes det en skadelidende part? Det er vanskelig å dokumentere med sikkerhet, men det er grunn til å frykte redusert kvalitet i pasientbehandlingen (9).
Til slutt kravet om systemsammenheng: Bygger prosessen med Oslo universitetssykehus på et særegent sett av oppfatninger? Mange har pekt på den nyliberale trenden new public management, som karakteriseres av fristilling og markedsretting (analogt til privat sektor) kombinert med oppbygging av byråkratiske kontrollsystemer (10). Norsk offentlig forvaltning har i stor utstrekning vært reformert etter disse prinsippene siden 1980-årene. Etter hvert er reformene blitt sin egen begrunnelse - dels fordi de kan gi inntrykk av politisk handlekraft, dels fordi firmaer og organisasjoner kan ha reformer som hovedoppgave eller forretningsidé (10). At reformer er nødvendige, er altså i seg selv et ideologisk standpunkt.

Mye kan altså tale for at prosessen var ideologisk begrunnet. Dette bør skjerpe mistenksomheten overfor nye helsepolitiske reformer, for eksempel nedleggelse av lokalsykehusene. Det påstås ofte at god pasientbehandling krever store enheter, men bygger dette argumentet på erfaring og fornuftig analyse? Eller er det snakk om realitetsfordreining? Empiriske studier kan tale for at små sykehus har kvalitetsmessige fortrinn $(11,12)$. Hva med samhandlingsreformen - tåler dens premisser et slikt kritisk søkelys?

Ideologiens selvimmunisering kan være skadelig for samfunnet og dermed for de formål som ideologien selv påstår å fremme (1). Lydhørhet overfor kritiske røster vil gi større evne til å løse fremtidige samfunnsutfordringer. Som fagpersoner kan vi med fordel utvikle en kritisk mistenksomhet når det gjelder helsepolitiske reformer og etterspørre fornuftige begrunnelser - på samme måte som vi ville gjort med nye programmer for pasientbehandling.

\section{Litteratur}

1. Skirbekk S. Ideologi, myte og tro ved slutten av et århundre. Oslo: Tano Aschehoug, 1999.

2. Slagstad R. Helsefeltets strateger. Tidsskr Nor Legeforen 2012; 132: 1479-85. 3. Fulop N. Protopsaltis G. Hutchings A et al. Process and impact of mergers of NHS trusts: multicentre case study and management cost analysis. BMJ 2002; 325: 246

4. Pellegrini VD Jr. Mergers involving academic health centers: a formidable challenge. Clin Orthop Relat Res 2001; 391: 288-96.

5. Andvig JC. Sanger fra andre etasje - forfallet i det offentlige. Nytt Norsk Tidsskrift 2001; 18: 188-96.

6. Innst. S. nr. 262 (2007-2008). Innstilling fra helse- og omsorgskomiteen om helse- og omsorgsministerens redegjørelse 26. februar 2008 om den økonomiske situasjonen ved landets helseforetak.

7. Grønli H, Eriksen KA. Ansatte tør ikke si hva de mener. NRK Nyheter 20.12.2011.

8. Oslo universitetssykehus HF. Protokoll lukket behandling, styremøte 29.9.2011. Sak 106/2011 «Diskusjon av styremedlemmers rolle».

9. Riksrevisjonens kontroll med forvaltningen av statlige selskaper for 2012. Dokument 3: 2 (2013-2014). Oslo: Riksrevisjonen, 2013.

10. Østerud $\varnothing$. Engelstad F, Selle P. Makten og demokratiet. Oslo: Gyldendal Akademisk, 2003.

11. Kristensen PK, Thillemann TM, Johnsen SP. Is bigger always better? A nationwide study of hip fracture unit volume, 30-day mortality, quality of in-hospital care, and length of hospital stay. Med Care 2014; 52: 1023-9.

12. Jullumstrø $E$, Wibe $A$, Lydersen $S$ et al. Colon cancer incidence, presentation, treatment and outcomes over 25 years. Colorectal Dis 2011; 13: 512-8. 